\title{
CD2 wt Allele
}

National Cancer Institute

\section{Source}

National Cancer Institute. CD2 wt Allele. NCI Thesaurus. Code C51120.

Human CD2 wild-type allele is located within $1 \mathrm{p} 13$ and is approximately $15 \mathrm{~kb}$ in length.

This allele, which encodes $T$-cell surface antigen $C D 2$, plays a role in immune recognition and facilitates helper $\mathrm{T}$ lymphocyte contact with antigen-presenting cells. 